\title{
KONSEP HUKUM MODERN: Suatu Perspektif Keindonesiaan, Integrasi Sistem Hukum Agama dan Sistem Hukum Nasional
}

\author{
Nasarudin Umar \\ IAIN Ambon \\ e-mail: nasaruddin_umar80@yahoo.com
}

\begin{abstract}
Indonesia is known as a country with a mixed legal system. The current legal system is dominated by three major legal systems, namely Western legal system, customary legal system and Islamic legal system. The mixing of legal system has been emerging problem, because basically each legal system has a different character. The most basic problem is unbalancing in the formation of legal system in consequence of the dominance of Western legal system from customary and religious legal system. This paper try to analyze the concept of integration of religious legal system in the national legal system to make its position can be balanced. Based on the analysis, the concept of Three Pillars of Modern Legal Systems is suitable for modern Indonesian legal system in order to integrate the diversity of cultures, customs and religions.
\end{abstract}

Indonesia dikenal sebagai negara dengan sistem hukum campuran. Sistem hukum yang saat ini berlaku didominasi oleh tiga sistem hukum besar, yaitu sistem hukum Barat, sistem hukum adat dan sistem hukum Islam. Percampuran sistem hukum ini bukan tak masalah, karena pada hakekatnya setiap sistem hukum memiliki karakter yang berbeda. Problem paling dasar adalah pembentukan hukum yang tidak berimbang, yaitu dominasi sistem hukum Barat atas hukum agama dan adat. Tulisan ini mengurai konsep integrasi sistem hukum agama dalam sistem hukum nasional agar kedudukannya dapat berimbang. Berdasarkan hasil analisa, konsep Three Pillars Sistem Hukum Modern yang integratif merupakan konsep hukum yang tepat untuk sistem hukum modern Indonesia dalam rangka mengintegrasikan keanekaragaman budaya, adat istiadat dan agama.

Keywords: integrasi sistem hukum, hukum agama, hukum nasional 


\section{A. Pendahuluan}

Membicarakan sistem hukum Indonesia berarti kita membahas hukum secara sistematik yang berlaku di Indonesia. Secara sistemik berarti hukum dilihat sebagai suatu kesatuan yang utuh, yang unsur-unsur, sub-subsistem atau elemen elemennya saling berkaitan, saling pengaruh memengaruhi serta saling memperkuat atau memperlemah antara satu dengan yang lainnya tidak dapat dipisahkan. Sebagai suatu sistem, hukum Indonesia terdiri atas sub sistem atau elemen-elemen hukum yang beraneka antara lain hukum tata negara, hukum perdata, hukum pidana serta hukum international serta norma-norma sosial, agama dan kebiasaan.

Sistem hukum Indonesia yang berlaku saat ini adalah bersumber dari tradisi sistem hukum adat, hukum Islam, dan hukum Barat yang merupakan tiga sistem hukum yang menjadi komponen utama dalam pembentukan hukum di Indonesia. Atau pendapat Achmad $\mathrm{Ali}^{1}$ bahwa Indonesia merupakan salah satu negara yang mempraktikkan mixed sytem atau sistem campuran di mana berlaku sistem hukum perundang-undangan, hukum adat dan hukum Islam. Apabila dikaitkan degan pendapat Eric L. Rischard dalam pengelompokan sistem hukum utama yang berkembang di dunia maka sistem hukum Indonesia merupakan sistem hukum Far East, (hukum Timur Jauh) yaitu sistem hukum yang kompleks yang merupakan perpaduan antara sistem civil law, common law dan hukum Islam sebagai basis fundamental masyarakat. Sistem hukum far east memiliki karakteristik yang penekanannya pada harmoni dan tatanan sosial, penghindaran dari proses hukum yang birokratis.

Tradisi sistem hukum Indonesia yang berhukum secara sistem campuran menimbulkan persoalan tersendiri karena hal tersebut disebabkan karena menggabungkan berbagai tradisi sistem hukum seperti sistem hukum adat, sistem hukum Islam, dan sistem hukum Barat dalam satu sistem hukum. Ketiga sistem hukum tersebut memiliki substansi dan karakteristik yang berbeda. Sistem hukum adat dibangun dari tradisi kerakyatan bersumber dari nilai-nilai kearifan lokal yang bersifat sektarian yang sangat sulit diterapkan secara umum seluruh lapisan masyarakat khususnya di Indonesia yang beragam suku, adat istiadat dan kebudayaan dan semakin mendapat tantangan dimasa modernisasi saat ini.

${ }^{1}$ Achmad Ali, Menguak Teori Hukum dan Teori Peradilan, (Jakarta: Kencana, 2009). h. 203 
Sistem hukum Islam merupakan sistem hukum yang dibangun berdasarkan wahyu ilahi tradisi ketuhanan dan sarat dengan nilai-nilai penghormatan terhadap kemanusiaan, yang diturunkan Sang Khaliq untuk seluruh umat manusia dan seluruh alam, originalitas dan internalisasinya ditaati oleh seluruh umat Islam di seluruh jagat raya ini, hukum Islam telah melewati perjalanan sejarah yang panjang seiring dengan peradaban manusia hingga sekarang ini.

Sedangkan sistem hukum Barat di Indonesia dibangun dari tradisi positivisme yang beranjak dari pemikiran Barat yang berpaham sekularistik, individualistik dan hendonism yang mengagung-agungkan nilai-nilai kebebasan manusia di atas nilai-nilai ketuhanan tidak sesuai dengan budaya Indonesia. Sistem hukum ini lahir dari hukum Romawi (corpus luris civilis) yang kemudian diadobsi oleh Perancis (code civil dan code commerce) dan Belanda (Burgelijk Wetboek, dan Wetboek van Strafrecht dan Wetboek van Koophandel) pada tahun 1858 hingga dipaksakan berlakunya di Indonesia selama berabad-abad mulai Januari 1848 (oleh Mr. C.J. Scholten dan M. Meyer) hingga sekarang ini berdasarkan aturan peralihan UUD NRI Tahun $1945^{2}$.

Problem yang paling mendasar dalam sistem hukum Indonesia alam praktek pembentukan hukum (law making) di Indonesia ketiga sistem hukum tidak diadobsi secara tidak berimbang sistem hukum Barat lebih mendominasi sistem hukum nasional, sehingga sistem hukum agama dan adat kebiasaan kurang memiliki ruang untuk ditegakkan oleh negara. Sehingga dampaknya cara berhukum pemerintahan sangat positifistik atau berhukum secara normatif ala Barat (kebelandaan). Itulah sebabnya sistem hukum adat dan sistem hukum Islam di Indonesia tidak berkembang dan tidak terserap dengan baik dalam sistem hukum nasional, indikasi tersebut dapat dilihat dari presentase produk hukum perundang-undangan yang dihasilkan oleh negara lebih banyak mengadopsi sistem hukum Barat seperti KUH perdata, KUH Pidana, KUH Dagang, hukum Hak Asasi Manusia (HAM), sistem peradilan, sistem perundangundangan, sistem ketatanegaraan dan sistem pemerintahan pusat dan daerah berkarakter kebelandaan dan kebar-baratan, yang jika dipresentasekan secara bebas tidak kurang dari 80-90\% sistem hukum nasional dibangun dan berwatak

\footnotetext{
2Segala peraturan perundang-undangan yang masih ada tetap berlaku selama belum diadakan yang baru menurut Undang-Undang Dasar ini.
} 
hukum Barat sedangkan hanya 10-20\% diterapkan sistem hukum Islam dan sistem hukum adat hanya untuk perkara-perkara tertentu yaitu hukum perkawinan dan kewarisan, urusan haji dari hukum Islam sedangkan hukum agraria dan pertanahan diadobsi dari hukum adat.

Dalam konteks pembangunan hukum Indonesia, tuntutan untuk merevisi bahkan mengganti berbagai peraturan perundang yang bersumber dari kolonial Belanda seperti KUH Pidana, KUH Perdata yang sudah tidak sesuai dengan jati diri bangsa Indonesia, pembaruan ketentuan tersebut merupakan keharusan sejarah dan keharusan konstitusional yang tidak bisa ditawar lagi.

Nilai-nilai asing seperti nilai-nilai kebebasan, kapitalisme, nilai-nilai hendonisme yang sangat kental dalam produk hukum kolonial tersebut telah banyak membentuk watak masyarakat dan merusak mental masyarakat akhirnya menggeser nilai-nilai agama, budaya masyarakat Indonesia yang sudah lama dianut.

Demikian pula dalam sepuluh tahun terakhir ini, banyak bermunculan peraturan perundang-undangan yang bernuansa keagamaan seperti UU Otonomi Khusus Aceh, UU Haji, UU Zakat, UU Perbankan Syariah, UU Pornografi, Perda Anti Maksiat, Perda Pelarangan Minuman Keras, Perda Berbusana Muslim, Perda Baca tulis al-Qur'an dan sebagainya. Perkembangan tersebut adalah cerminan kebutuhan hukum masyarakat yang tinggi terhadap tuntutan hukum yang bersumber dari kearifan nilai-nilai agama dari berbagai komponen negeri ini untuk menginginkan modernisasi hukum nasional dalam berbagai bidang dalam mengatasi permasalahan bangsa dewasa ini.

Oleh karena itu, negara Indonesia memerlukan suatu sistem hukum modern yaitu seperangkat atau suatu sistem hukum yang mampu mengantisipasi serta mengatasi berbagai permasalahan yang mungkin akan timbul. Indonesia sebagai salah satu negara di dunia ini tidak terlepas dari pengaruh arus globalisasi. Sebagai akibat dari globalisasi, juga menimbulkan dampak di bidang hukum serta diperlukannya konsep integrasi sistem hukum agama dalam sistem hukum nasional

Berangkat dari keadaan demikian, maka dalam tulisan ini akan mengurai konsep integrasi sistem hukum agama dalam sistem hukum nasional. Agar tulisan ini akan lebih mendalam menjelaskan hal itu. Dan labih lanjut lagi akan menguria konsep hukum modern dalam persepektif keindonesiaan. 


\section{B. Konsep Hukum Modern dalam Perspektif Keindonesiaan}

Kata "modernisasi" adalah hal atau tindakan menjadikan modern (terbaru, mutakhir). ${ }^{3}$ Secara etimologi, kata modern berasal dari bahasa Latin moderma yang berarti masa kini, terbaru atau mutakhir. Modern biasa juga berarti sekarang, baru atau saat ini. ${ }^{4}$

Dalam Kamus Besar Bahasa Indonesia kata modern diartikan sikap, cara berpikir serta cara bertindak sesuai dengan tuntutan zaman. ${ }^{5}$ Kata modern dapat ditelusuri dalam beberapa hal: pertama, berhubungan dengan waktu (sejarah); kedua, berhubungan dengan penemuan-penemuan dalam bidang ilmu pengetahuan, dan yang ketiga, berhubungan dengan pikiran (ideologi). Gagasan modern sering dipahami sebagai gagasan pembaruan dan dipertentangkan dengan gagasan tradisional. ${ }^{6}$

Menurut Donald Eugen Smith, ${ }^{7}$ batasan-batasan tentang modernisasi sering kali ditekankan pada aspek-aspek perubahan di bidang teknologi dan ekonomi. Akan tetapi, sebagaimana dikemukakan Manfret Halpern bahwa "revolusi modernisasi melibatkan transformasi semua sistem yang dipakai orang untuk mengatur masyarakatnya, baik sistem politik, sosial, ekonomi, intelektual, keagamaan maupun psikologi". ${ }^{8}$ Hukum juga merupakan salah satu sistem yang dipakai untuk mengatur kehidupan masyarakat. Demikian juga dari sudut pandang Islam, sekularisasi harus dijauhkan dari proses modernisasi. Modernisasi atau pembangunan tidaklah harus dibarengi dengan sekularisasi seperti pendapat Smith. ${ }^{9}$

Berdasarkan pengertian modernisasi di atas maka modernisasi hukum di Indonesia dalam tulisan ini adalah pembaruan hukum di bidang peraturan

\footnotetext{
${ }^{3}$ Kamus Bahasa Indonesia, (Jakarta: Pusat Bahasa Deprtemen Nasional, 2008), h. 965.

${ }^{4}$ Nurcholish Madjid, Islam dan Kemodernan (Bandung: Mizan, 1987), h. 63.

5Tim Penyusun Kamus Pusat Pembinaan dan Pengembangan Bahasa Departemen Pendidikan dan Kebudayaan, Kamus Besar Bahasa Indonesia (KBBI) (Jakarta: Balai Pustaka, 1991), h. 662.

${ }^{6}$ Ahmad Mubarak, Relevansi Tasawuf dengan Problem Manusia Modern, dalam Nurcholis Madjid, dkk. Manusia Modern Mendambah Allah Renungan Tasawuf Positif, ed., Ahmad Nadjib Burhani, (Jakarta: Iman dan Hikma, 2002), h.167-168. Lihat: juga Hj. St. Nurhayati "Tasawuf Pada Abad Modern: Solusi Problem Manusia Menurut Seyyed Hossein Nasr", Disertasi, (Makassar: PPS UIN Alauddin, 2013), h.24.

7Donald Eugene Smith, Religion and Political Developmen an Analytic Study, (Boston: Massachusetts, Little, Brown and Company, 1970), diterjemahkan oleh Machnun Husein, Agama dan Modernisasi Politik Suatu Kajian Analitis, (Jakarta: Rajawali, 1985), h.5.

8Manfred Halpern, "Toward Futher Modernization of the Study of New Nations", World Politics, No. 17 (October 1964), h. 173.

${ }^{9}$ Manfred Halpern, "Toward Futher Modernization of the Study of New Nations”, h. xv.
} 
perundang-undangan baik dalam konteks peraturan perundang-undangan yang sudah tidak sesuai dengan konteks kekinian dan kebutuhan hukum bangsa Indonesia maupun lahirnya undang-undang yang bernuansa keagamaan, khususnya syariat Islam yang mewarnai perkembangan hukum nasional dalam satu dekade terakhir ini.

Sebab konsep hukum modern yang telah digagas oleh para ahli terdahulu seperti Max Weber, Galenter dan Charles Samprod yang mengilhami konsep negara hukum di negara-negara Barat pada umumnya, tidak sepenuhnya dapat ditegakkan di Indonesia yang memiliki karakteristik ketimuran dan perdaban yang berbeda dengan negara Barat pada umumnya. Di antaranya dalam perbedaan dalam meletakkan hubungan hukum agama dan hukum negara.

Konstitusi Indonesia Pasca Amandemen 1999-2002 telah memberikan paradigma hukum konstitusional yang modern di Indonesia. Hal ini disampaikan Amin Rais dalam sambutannya dalam sidang paripurna MPR tahun 2000 tersebut mengatakan bahwa Sidang Tahunan MPR Tahun 2000 telah menghasilkan Perubahan Kedua Undang-Undang Dasar Negara Republik Indonesia (UUD NRI) Tahun 1945. Dengan hasil ini majelis mempersembahkan kepada bangsa sebuah konstitusi modern, konstitusi yang mengakomodasi asas konstitusionalisme dan prinsip demokrasi universal, sebagaimana konstitusi negaranegara yang telah lebih dulu maju dan demokratis. ${ }^{10}$

Amin Rais hendak menegaskan bahwa hukum modern dalam perspektif UUD NRI Tahun 1945 adalah perpaduan asas konstitusionalisme dan prinsip demokrasi universal. Salah satu prinsip baru dalam konstitusi Indonesia pasca amandemen adalah ditegaskannya nilai-nilai agama, nilai-nilai budaya, nilai-nilai kemanusiaan sebagai bagian integratif dari nilai fundamental yakni Pancasila hal tersebut menunjukkan suatu potret kesatuan hukum modern Indonesia.

Undang-Undang Dasar Negara Republik Indonesia (UUD NRI) Tahun 1945 mengandung butir-butir pasal yang tidak hanya merupakan pintu gerbang masuknya norma-norma hukum yang secara kuantitatif maupun kualitatif sangat memenuhi kebutuhan masyarakat Indonesia, karena sifatnya sangat membuka diri bagi masuknya nilai-nilai agama dalam sistem hukum maupun hukum positif

\footnotetext{
${ }^{10}$ Sekretariat Jenderal MPR RI, Risalah Perubahan UUD NRI Tahun 1945 Tahun Sidang 2000, Buku Tujuh, Edisi Revisi, Sekretariat Jenderal MPR RI, 2010. h. 694.
} 
nasional kita, sekaligus juga akan menjadi motor pendorong, lahirnya sebuah sistem hukum positif nasional pada masa-masa mendatang. ${ }^{11}$

Karena itu setiap sistem hukum nasional dan penyusunan peraturan perundang-undangan harus memperhatikan cita-cita moral dan cita-cita hukum sebagaimana diamanatkan oleh Pancasila. Adapun nilai-nilai yang bersumber pada pandangan filosofi Pancasila, yakni:

1. Nilai-nilai religius bangsa Indonesia yang terangkum dalam sila Ketuhanan Yang Maha Esa.

2. Nilai-nilai hak-hak asasi manusia dan penghormatan terhadap harkat dan martabat kemanusiaan sebagaimana terdapat dalam sila Kemanusiaan yang adil dan beradab.

3. Nilai-nilai kepentingan bangsa secara utuh, dan kesatuan hukum nasional seperti yang terdapat dalam sila Persatuan Indonesia.

4. Nilai-nilai demokrasi dan kedaulatan rakyat. Sebagaimana terdapat di dalam sila Kerakyatan yang dipimpin oleh hikmah kebijaksanaan dalam permusyawaratan/perwakilan.

5. Nilai-nilai keadilan, baik individu maupun sosial seperti yang tercantum dalam sila keadilan sosial bagi seluruh rakyat Indonesia. ${ }^{12}$

Hal ini ditegaskan dalam Penjelasan Pasal 2 UU RI No. 12 Tahun 2011 tentang Pembentukan Peraturan Perundang-undangan, bahwa Penempatan Pancasila sebagai sumber dari segala sumber hukum negara adalah sesuai dengan Pembukaan Undang-Undang Dasar Negara Republik Indonesia Tahun 1945 alinea keempat yaitu Ketuhanan Yang Maha Esa, Kemanusiaan yang adil dan beradab, Persatuan Indonesia, Kerakyatan yang dipimpin oleh hikmat kebijaksanaan dalam Permusyawaratan/Perwakilan, dan Keadilan sosial bagi seluruh rakyat Indonesia. Menempatkan Pancasila sebagai dasar dan ideologi negara serta sekaligus dasar filosofis negara sehingga setiap materi muatan Peraturan Perundang-undangan tidak boleh bertentangan dengan nilai-nilai yang terkandung dalam Pancasila.

\footnotetext{
${ }^{11}$ Hartono Mardjono, Menegakkan Syariat Islam dalam Konteks Keindonesiaan, Proses Penerapan Nilai-Nilai Islam, dalam Aspek Hukum, dan Lembaga Negara, (Bandung: Mizan, 1997), h.28.

12Zainuddin, "Implikasi Pengelolaan Zakat terhadap Keadilan Sosial di Indonesia", Disertasi, tidak diterbitkan, (Makassar: Universitas Hasanuddin, 2011), h. 295.
} 
Jaringan nilai-nilai dalam Pancasila diharapkan memperkuat sistem hukum nasional untuk senantiasa surveive dalam menghadapi modernisasi yang terjadi di dalam masyarakat akibat era globalisasi dewasa ini.

Perkembangan dunia dewasa ini yang semakin maju dan terus berkembang pesat, ditandai dengan perkembangan ilmu pengetahuan dan teknologi. Akibat kemajuan komunikasi, informasi dan transportasi hampir dapat dikatakan tidak terdapat batas-batas wilayah lagi sebagai akibat arus informasi tersebut. Perkembangan tersebut seakan-akan telah menjadi nilai baru masyarakat modern. Arus informasi tersebut, baik dari dalam maupun dari luar tidak mungkin terkendali, dan dihindarkan. Oleh sebab itu, perlu ada semacam jaringan nilai-nilai untuk menjaring nilai-nilai yang tidak sesuai dengan pandangan hidup bangsa.

Suatu sistem hukum yang modern harus juga merupakan hukum yang baik, dalam arti hukum tersebut harus mencerminkan rasa keadilan bagi para pihak yang terlibat atau diatur oleh hukum tersebut. hukum tersebut harus sesuai dengan kondisi masyarakat yang diaturnya. Hukum tersebut harus dibuat sesuai dengan prosedur yang ditentukan. Juga suatu hukum yang baik harus dapat dimengerti atau dipahami oleh para pihak yang diaturnya. ${ }^{13}$ Karena itu salah satu dimensi mutlak dalam pembentukan sistem hukum Indonesia yang modern adalah senantiasa mencerminkan rasa keadilan masyarakat Indonesia dan sesuai cita hukum dan cita-cita moral dalam nilai-nilai Pancasila dan UUD NRI tahun 1945.

Negara Indonesia memerlukan suatu sistem hukum modern yaitu seperangkat atau suatu sistem hukum yang mampu mengantisipasi serta mengatasi berbagai permasalahan yang mungkin akan timbul. Indonesia sebagai salah satu negara di dunia ini tidak terlepas dari pengaruh arus globalisasi. Sebagai akibat dari globalisasi, juga menimbulkan dampak di bidang hukum.

Sebab konsep hukum modern yang telah digagas oleh para ahli terdahulu seperti Max Weber, Galenter dan Charles Samprod yang mengilhami konsep negara hukum di negara-negara Barat pada umumnya, tidak sepenuhnya dapat ditegakkan di Indonesia yang memiliki karakteristik ketimuran dan perdaban yang berbeda dengan negara Barat pada umumnya. Di antaranya dalam perbedaan dalam meletakkan hubungan hukum agama dan hukum negara. Karena itu sebelum membahas konsep hukum modern dalam perspektif keindonesiaan

${ }^{13}$ Otje Salman, dkk, Beberapa Sosiologi Hukum, (Bandung: Alumni, 2012), h. 90-91. 
maka terlebih dahulu melihat pemikiran hukum modern dalam telah digagas Max Weber dan Marc Galater.

Konsep hukum modern dalam pandangan Max Weber yakni memiliki ciriciri sebagai berikut:

1. Aturan-aturan hukum memiliki suatu kualitas normatif yang umum dan lebih abstrak.

2. Hukum modern adalah hukum positif, hasil keputusan yang diambil secara sadar.

3. Hukum modern diperkuat oleh kekuasaan yang memaksa dari negara dalam bentuk sanksi yang diberikan dengan sengaja, dikaitkan dengan aturanaturan hukum yang dapat berlaku melalui pengadilan-pengadilan, bilamana terjadi atas pelanggaran aturan-aturan tersebut.

4. Hukum modern adalah sistematis, aturan-aturannya, prinsip-prinsipnya, konsep-konsepnya dan doktrin-doktrinnya yang berbeda-beda. Serta bagian hukum prosedural dan hukum material yang bermacam-macam, berhubungan satu sama lain sedemikian rupa sehingga merupakan suatu sistem pemikiran normatif yang logis, rasional, atas dasar di mana semua problem praktis yang bersifat hukum, pada prinsipnya dapat dipecahkan menurut hukum.

5. Hukum modern adalah sekular, substansinya sama sekali terpisah dari pertimbangan keagamaan dan etis, artinya kesahian tidak lagi tergantung dari kebenaran moralnya dan prosedur-prosedurnya dibebaskan dari artiarti magis dan telah menjadi upaya rasional untuk mencapai maksudmaksud yang rasional. ${ }^{14}$

Salah satu konsep hukum modern yang dituliskan oleh Max Weber adalah bahwa Hukum modern adalah sekular, substansinya sama sekali terpisah dari pertimbangan keagamaan dan etis.

Dari segi peristilahan sekularisasi didefinisikan sebagai proses yang menuju pada keadaan yang sekuler atau proses netralisasi dari setiap pengaruh agama. ${ }^{15}$ Yaitu paham yang ingin memisahkan atau menetralisasi semua bidang ke-

\footnotetext{
${ }^{14}$ Yesmin Anwar dan Adang, Sistem Peradilan Pidana (Konsep, Komponen, dan Pelaksanannya Dalam Penegakan Hukum di Indonesia), (Bandung: Widya Padjajaran, 1988), h. 2-3. Selanjutnya dapat dibaca dalam A.A.G. Perter dan Koesriani Siswosoebroto, Hukum dan Perkembangan Sosial: Buku Teks Sosiologi Hukum, (Jakarta: Pustaka Harapan, 1988), h.368-369.

15Tahir Azhary, Negara Hukum: Suatu Study tentang Prinsip-prinsipnya Dilihat dari Segi Hukum Islam, Implementasinya pada Periode Negara Madinah dan Masa Kini, (Jakarta:Bulan Bintang, 2003), h. 102.
} 
hidupan, seperti politik dan kenegaraan, ekonomi, hukum, sosial-budaya dan ilmu pengetahuan-teknologi dari pengaruh agama. ${ }^{16}$

Tahir Azhary menegaskan rujukan paham sekularisme menurut penentangnya adalah Injil, dalam Matheus 22: 21

Render unto Caesar, the things which are caesar's and unto God the things which are God's

(berikanlah kepada penguasa duniawi hal-hal yang berhubungan dengan urusan duniawi, dan serahkanlah kepada Tuhan segala urusan yang berhubungan dengan Tuhan). ${ }^{17}$

Paham ini lekat di hati peradaban Eropa yang memisahkan agama dan negara. ${ }^{18}$ Menurut Amin Rais, doktrin Nasrani tentang sekularisasi sama sekali tidak dikenal dalam Islam. Ia menyebut sekularisasi sebagai "semacam kelatahan intelektual". 19

Perspektif Max Weber tentang hukum modern yang memisahkan hukum dengan pertimbangan keagamaan dan etis, jelas tidak relevan jika diterapkan di Indonesia. Karena dalam perspektif Pancasila dan UUD NRI Tahun 1945 agama, moral, hukum dan negara adalah satu kesatuan yang tidak terpisahkan.

Hal ini di dasarkan oleh sejumlah pandangan di antaranya, pandangan dari M. Rasjidi yang mengemukakan tiga macam penyelesaian tentang sampai di mana terdapat hubungan hukum dan moral sebagaimana dibahas dalam filsafat hukum umum yaitu:

1. Hukum dan moral harus berdampingan karena moral merupakan pokok hukum.

2. Masing-masing hukum dan moral ada bidangnya, tetapi moral lebih tinggi dari hukum.

3. Masing-masing hukum dan moral ada bidangnya sendiri yang tiada hubungannya satu sama lain.

Lebih lanjut ia mengatakan dalam hubungan hukum dan moral menurut ajaran Islam tercermin terutama dalam hal sebagai berikut:

\footnotetext{
16Tahir Azhary, Negara Hukum: Suatu Study tentang Prinsip-prinsipnya..., h. 13.

17Tahir Azhary, Negara Hukum: Suatu Study tentang Prinsip-prinsipnya..., h. 33-34.

${ }^{18}$ Hamka, Islam: Islam Revolusi Ideologi dan Keadilan Sosial, Editor: Rusjdi, Oakarta: Pustaka Panjimas, 1984), h.80.

${ }^{19}$ Jazuni, Legislasi Hukum Islam di Indonesia, (Bandung: Citra Aditya Bakti, 2010), h. 51-52.
} 
1. Beberapa ketentuan hukum Islam mempertahankan tegaknya moral luhur, seperti dalam hukum pidana yang menentukan bahwa perzinaan adalah delik moral yang diancam dengan pidana cambuk 100 kali, tanpa memerlukan aduan pihak yang bersangkutan.

2. Beberapa ketentuan hukum Islam mengandung nilai moral luhur, seperti terdapat dalam ketentuan hukum muamalat yang mengajarkan agar orang yang berpiutang mengalami kesulitan untuk membayar utangnya pada waktu yang telah ditentukan dalam perjanjian.

3. Dalam melaksanakan hukum hendaknya dilandasi dengan nilai moral luhur yang bertumpu pada sikap patuh, taat dan rela melaksanakan ketentuan hukum yang telah ditetapkan al-Qur'an dan sunnah Rasul untuk menghindari ketentuan hukum bertentangan dengan nilai moralitas Islam. ${ }^{20}$

Berikutnya karakteristik sistem hukum modern dikemukakan oleh Marc Galanter, ia mengatakan bahwa hukum modern memiliki karakteristik seperti: ${ }^{21}$ Hukum uniform terdiri dari peraturan-peraturan yang uniform dan tidak berbeda pula dengan penerapannya. Penerapan hukum ini lebih cenderung bersifat teritorial daripada personal. Artinya, bahwa peraturan-peraturan yang sama dapat diterapkan bagi umat segala agama, warga semua suku bangsa, daerah kasta dan golongan. Perbedaan di antara pribadi-pribadi yang diakui oleh hukum bukanlah perbedaan dalam makna intrinsik atau kualitas, tetapi perbedaan fungsi, kondisi, dan prestasi dalam tuntutan-tuntutan duniawi;

Hukum uniform terdiri dari peraturan-peraturan yang uniform dan tidak berbeda pula dengan penerapannya. Penerapan hukum ini lebih cenderung bersifat teritorial daripada personal. Artinya, bahwa peraturan-peraturan yang sama dapat diterapkan bagi umat segala agama, warga semua suku bangsa, daerah kasta dan golongan. Perbedaan di antara pribadi-pribadi yang diakui oleh hukum bukanlah perbedaan dalam makna intrinsik atau kualitas, tetapi perbedaan fungsi, kondisi dan prestasi dalam tuntutan-tuntutan duniawi.

Dalam konteks keindonesiaan konsep hukum modern dengan konsep hukum uniform Galanter tidak selalu dapat dijalankan, mengingat keragaman budaya, ras, agama di Indonesia adalah suatu keniscayaan yang tidak mungkin

\footnotetext{
${ }^{20}$ Ahmad Azhar Basyir, Hubungan Agama dan Pancasila, (Yogyakarta: Universitas Islam Indonesia, 1985), h. 58.

21Teguh Prasetyo.,dkk., Ilmu Hukum dan Filsafat Hukum, Studi Pemikiran Ahli Hukum Sepanjang Zaman, (Yogyakarta: Pustaka Pelajar, 2007), h. 198-201.
} 
disatukan dengan satu unifikasi hukum semata. Karena dalam kondisi tertentu penerapan hukum ini lebih cenderung bersifat personal dari pada teritorial. Artinya, bahwa peraturan-peraturan yang khusus dapat diterapkan bagi umat tertentu, warga atau suku bangsa, daerah khusus, dan golongan tertentu.

Sistem hukum Indonesia mengakui dan menjamin adanya satuan-satuan masyarakat hukum adat dan kekhususan agama tertentu. Sehingga dimungkinkan adanya undang-undang yang berlaku khusus bagi umat agama dan kesatuan adat tertentu. Keberlakuannya pun hanya mengikat subjek hukum bagi umat agama atau kesatuan adat tertentu. Ini menunjukkan adanya ruang yang bersifat khusus dalam keberlakuan suatau peraturan perundang-undangan di Indonesia.

Menurut Jazuni, di Indonesia keberlakuan suatu undang-undang dapat dilihat dalam undang-undang yang bersangkutan. Adakalanya hukum berlaku secara nasional, di semua daerah dan kepada semua warga negara. Akan tetapi, ada juga hukum yang hanya berlaku bagi mereka yang berkualifikasi tertentu, misalnya warga negara yang beragama Islam. Dalam kaitan ini, ketentuan-ketentuan dalam hukum Islam ada yang dapat diberlakukan secara umum kepada semua warga negara, yaitu nilai-nilai universalnya (yang diajarkan semua agama) dan ada pula dalam hal ini umat Islam, yaitu aturan-aturan hukum yang khusus berlaku bagi Muslim tidak bagi umat lain. Hal ini dapat digambarkan sebagai berikut:

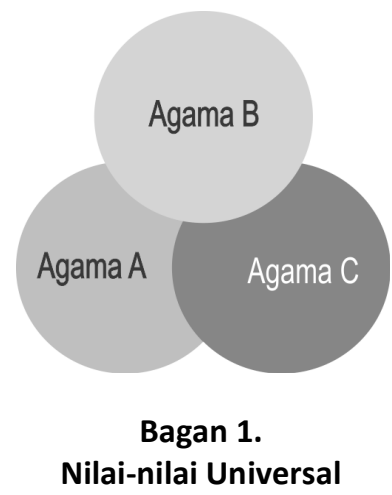

Untuk nilai-nilai universal yang diajarkan oleh semua agama atau yang dapat diterima oleh pemeluk semua agama (pada gambar terletak di tengah, merupakan persinggungan dari agama-agama yang ada), dapat dilegislasikan dan diberlakukan secara nasional kepada semua warga negara. Untuk nilai-nilai partikular yang hanya diajarkan oleh agama tertentu atau hanya menyangkut ke- 
pentingan (pemeluk) agama tertentu (pada gambar, agama A saja, atau agama B saja, atau agama C saja), jika dilegislasikan, hanya dapat diberlakukan kepada pemeluk agama tertentu tersebut. jika yang dilegislasikan adalah hukum Islam yang menyangkut kepentingan umat Islam, ia hanya diberlakukan kepada umat Islam.22

Perundang-undangan khusus yang melayani kepentingan golongan agama tidak dimaksudkan sebagai suatu pengaturan materi yang diskriminatif dan sewenang-wenang. Adanya ciri-ciri dan karakteristik pada golongan agama menimbulkan legal distinction bukan suatu diskriminasi yang sewenang-wenang sehingga tidak dapat dipandang sebagai suatu inequality before the law. Menurut pemerintah, hukum nasional harus diartikan satu sistem hukum nasional yang di dalamnya terdapat subsistem hukum nasional sehingga kalimat "satu kesatuan hukum" tidak boleh diartikan terlalu sempit.

Bahwa prinsip equality before the law merupakan salah satu hak asasi manusia. Namun demikian, tidak mungkin serta tidak adil jika prinsip ini diterapkan kepada semua warga negara tanpa perbedaan dan dalam semua perundang-undangan, karena tanpa memperkecil arti prinsip equality before the law itu perbedaan-perbedaan yang asasi yang ada di antara warga Negara dapat dan seharusnya mendapatkan peraturan-peraturan yang berlainan dalam hukum. Legal distinction tidak harus dipandang sebagai inequality before the law. Sebaliknya, tidak dapat dikatakan equality before the law hanya dianggap sah apabila factual condition sama secara keseluruhan. Atas dasar itu selalu dapat dipikirkan pengaturan hukum mengenai suatu golongan. ${ }^{23}$

Karena itu konsep hukum modern menurut Max Weber dan Galanter dalam konteks keindonesiaan tidak sepenuhnya dapat dijalankan, karenanya diperlukan konsepsi baru dalam merumuskan konsep hukum modern yang cocok dengan karakteristik hukum di Indonesia.

Berbeda halnya dengan pandangan Charles Samprod dalam tulisannya Discuss of law antara lain menyatakan bahwa hukum modern adalah hukum yang substansinya sesuai dengan nilai-nilai keadilan masyarakat. Pandangan ini juga diperkuat oleh Angel dalam tulisannya Law Time and Community, Angel

\footnotetext{
22Jazuni, Legislasi Hukum Islam di Indonesia, (Bandung: Citra Aditya Bakti, 2010), h. 356-357.

${ }^{23}$ Keterangan Pemerintah atas Rancangan Undang-Undang tentang Peradilan agama pada Rapat Paripurna DPR RI tanggal 28 Januari 1989 dalam Jazuni, Legislasi Hukum Islam di Indonesia, (Bandung: Citra Aditya Bakti, 2010), h. 379-380.
} 
menyatakan bahwa hukum harus sesuai dengan nilai-nilai yang hidup dan berkembang di dalam masyarakat. ${ }^{24}$

Menurut Aswanto, secara teoritis hukum yang bertentangan dengan nilainilai yang hidup dan berkembang dalam masyarakat tidak dapat dianggap sebagai hukum modern. ${ }^{25}$ Oleh sebab itu nilai-nilai agama sebagai salah satu nilai yang hidup dan berkembang di masyarakat Indonesia menjadi salah satu indikator dalam menentukan apakah suatu hukum atau peraturan dapat disebut sebagai hukum yang modern.

Karakteristik Negara Indonesia dalam konstitusinya telah memposisikan nilai-nilai agama sebagai nilai-nilai konstitusional, sebagai hukum dasar peraturan perundang-undangan di Indonesia. Pancasila sebagai sumber dari segala sumber hukum negara yang di dalamnya memuat nilai tertentu seperti nilai Ketuhanan dalam sila Ketuhanan Yang Maha Esa mensyaratkan norma hukum di bawah UUD NRI Tahun 1945.

Kedaulatan yang pertama adalah kedaulatan Tuhan, kedaulatan Tuhan di dasarkan pada sila pertama Pancasila, "Ketuhanan Yang Maha Esa", mukaddimah UUD NRI Tahun 1945, bahwa kemerdekaan Indonesia ini ialah karunia Allah SWT "Atas berkat rahmat Allah Yang Maha Kuasa dan dengan didorong keinginan luhur, supaya berkehidupan kebangsaan yang bebas, maka rakyat Indonesia menyatakan dengan ini kemerdekaannya". Dan Pasal 29 ayat 1 UUD NRI Tahun 1945 “ Negara Indonesia Berdasarkan Ketuhanan yang Maha Esa”.

Salah satu karakteristik hukum Indonesia adalah tidak terlepas dari hukum dasarnya yakni Pancasila dan pokok pangkal segala sila ialah percaya kepada Tuhan, karena itu karakter hukum modern Indonesia adalah hukum yang "berketuhanan" karenanya negara Indonesia sendiri sebagai otoritas pemilik hukum di Indonesia pun sebagai negara yang berdasarkan Ketuhanan Yang Maha Esa, Pasal 29 Ayat 1 UUD NRI Tahun 1945.

Dalam tafsiran Hamka bahwa tiada di antara kita yang di dalam dirinya mengalir Iman, yang tidak paham bahwasanya Ketuhanan Yang Maha Esa, sebagai sila pertama dari falsafah negara kita, ialah bahwa kita percaya kepada Tuhan, dan Tuhan itu Esa adanya, tidak beranak dan tidak diperanakkan, dan

\footnotetext{
${ }^{24}$ Aswanto, "Paradigma di Balik Penyusunan Rancangan KUHP", makalah yang disampaikan pada, seminar publik "Kebebasan Berekspresi dalam Negara Demokrasi: Tinjauan Kritis terhadap RUU KUHP", di Makassar, tgl. 5 Juli 2006.

25Jazuni, Legislasi Hukum Islam di Indonesia, (Bandung: Citra Aditya Bakti, 2010), h. 379-380.
} 
tidak sesuatu pun yang menyamai-Nya. Kita jadikan dia dasar pertama dan utama dari negara kita. Artinya bahwa Negara Indonesia berketuhanan, tegasnya bahwa kita seluruh penduduk negara ini percaya akan adanya Tuhan. Dia dijadikan niat dasar pertama negara ini, bukanlah semata-mata jadi buah mulut atau sapu-tangan penghapus bibir (lip-service, kata bung Hatta). Dia adalah dasar pertama sebagai dasar niat kita bermasyarakat dan bernegaraa. Supaya dijadikan titik tolak kita berpikir. Apa saja yang kita kerjakan, kita amalkan dan kita usahakan dalam negara ini ialah dengan niat mencapai ridha Allah.

Konstitusi Indonesia pasca amandemen dapat dikatakan sebagai konstitusi yang kombinatif karena mampu mengakomodir keanekaragaman hukum Indonesia. Keanekaragaman hukum di Indonesia dapat dilihat dari diakomodirnya tiga nilai-nilai baru dalam konstitusi. Nilai-nilai konstitusional itu adalah, nilainilai agama, nilai-nilai budaya dan nilai-nilai kemanusiaan (hak asasi manusia). Ketiga nilai-nilai dasar itu diatur secara berdampingan dalam UUD NRI Tahun 1945.

Ketiga dimensi nilai tersebut dapat pula dikatakan telah merefresentasikan nilai-nilai yang hidup di dalam kesadaran dan keadilan masyarakat Indonesia secara umum, meskipun nilai-nilai kemanusiaan dalam hak asasi manusia merupakan nilai yang diadobsi dari hukum Internasional, namun substansi dan spiritnya telah disesuaikan dengan karakteristik keindonesiaan.

Karenanya kombinasi ketiga dimensi nilai tersebut akan memenuhi rasa keadilan masyarakat di masa yang akan datang, karena nilai-nilai tersebut telah lama hidup dan mengakar di Indonesia, menjadi satu kesatuan sistim nilai dalam kehidupan bermasyarakat dan bernegara. Salah satu keistimewaan hukum nasional saat ini karena memberikan jaminan konstitusional terhadap keberlangsungan hukum agama, hukum adat baik keberlakuannya secara normatif (diberlakukan secara hukum kebiasaan) maupun keberlakuan ditegakkan secara yuridis melalui regulasi peraturan perundang-undangan negara dan sedangkan hukum-hukum Barat dan hukum universal lainnya terlebih dahulu diratifikasi melalu suatu perjanjian internasional dan melalui undang-undang.

Hukum hanya mungkin berlaku efektif dalam masyarakat, apabila hukum itu mencerminkan nilai-nilai yang secara filosofi diyakini kebenarannya oleh masyarakat tempat hukum itu diberlakukan. Apabila ada produk hukum yang tidak sejalan atau bertentangan dengan nilai-nilai filosofis yang diyakini kebenarannya oleh bangsa Indonesia (terutama oleh umat Islam yang jumlahnya mayoritas), maka konsekuensinya, hukum itu pasti tidak akan bisa dilaksanakan, sebagai- 
mana seharusnya hukum itu berlaku. Bahkan mungkin hal itu akan menjadi pemicu pertentangan antara rakyat dengan penguasa telah menyimpang dari nilai-nilai kebenaran yang diyakini. Sebaliknya apabila hukum itu mencerminkan nilai-nilai kebenaran dan keadilan yang hidup di dalam masyarakat, maka hukum itu akan mudah diterima dan dilaksanakan oleh mereka.

Karena itu berdasarkan uraian di atas penulis sampai pada suatu penegasan bahwa, sistem hukum Indonesia memiliki karakter hukum modern, kemodernan hukum Indonesia sangat terlihat adanya konfigurasi hukum yang sangat dinamis dan terbuka dalam struktur UUD NRI Tahun 1945 pasca amandemen, pengakuan dan jaminan negara terhadap berbagai sub sistem hukum yakni, sistem hukum adat, sistem hukum agama, sistem hukum internasional, diikat oleh satu kesatuan sistem hukum pancasila. Sehingga ciri hukum modern dalam perspektif keindonesiaan, dapat disusun sebagai berikut:

1. Aturan-aturan hukumnya berdasar atas kombinasi hukum yang bersumber dari Allah dan akal manusia

2. Hukum modern Indonesia dibingkai oleh tiga konsep kedaulatan dalam sistem hukum nasional yaitu kedaulatan Tuhan, kedaulatan rakyat dan kedaulatan negara tanpa mempertentangkan dan memisahkan satu sama lain.

3. Hukum modern Indonesia adalah kombinatif, hukum yang substansinya mengkombinasikan nilai-nilai hukum agama, nilai-nilai moral, nilai-nilai hukum adat dan nilai-nilai hukum Barat dalam satu kesatuan sistem hukum nasional yang diadobsi secara proporsional.

4. Hukum modern Indonesia adalah tidak sekuler, ketentuan substansi hukumnya tidak memisahkan agama, hukum dan moral etis. Ketiganya dipadukan sebagai satu kesatuan dalam merespons berbagai persoalan sosial. Artinya hukum Indonesia yang modern adalah hukum yang tidak menghendaki materialisem yang terlepas bebas. Demikian pula hukum Indonesia modern adalah hukum yang tidak memisahkan moral dan hukum. Dan hukum Indonesia modern merupakan hukum yang tidak membenarkan marxisme dan tidak pula membenarkan kapitalisme.

5. Hukum modern Indonesia adalah plural hukum yang mengayomi persamaan dan keberagaman, suku, ras, budaya, dan adat istiadat. Artinya Hukum modern Indonesia adalah mengakar pada kesadaran hukum masyarakat yang sinergis, hukum mengsinergikan berbagai kekhususan dan ke- 
istimewaan baik satuan-satuan daerah istimewa maupun kesatuan-kesataun masyarakat karena adat istiadat dan syariat agama.

6. Hukum Modern Indonesia adalah responsif dan visioner terhadap kebutuhan hukum dan perkembangan serta dinamika masyarakat baik pengaruh dari budaya luar maupun dalam budaya Indonesia sendiri. Seperti demokrasi, HAM dan hukum lokal dan lain-lain.

7. Hukum Indonesia modern adalah hukum yang tidak semata-mata berorientasi pada kepentingan umum tetapi juga berorientasi untuk memelihara, dan menjaga kepentingan serta kemaslahatan agama, akal, akhlak, harta dan jiwa. Perlindungan hukum yang konverehensif ini berdasarkan tujuan pembentukan negara Indonesia dalam alenia ke-4 Pembukaan UUD NRI Tahun 1945 yakni, melindungi segenap dan seluruh tumpa darah Indonesia.

\section{Konsep Integrasi Sistem Hukum Agama dan Sistem Hukum Nasional}

Berdasarkan konsep hukum modern dalam konteks keindonesiaan di atas maka perpaduan nilai-nilai, prinsip-prinsip, dan norma-norma agama dengan nilai-nilai dan prinsip-prinsip dan norma hukum positif negara merupakan kolaborasi yang ideal dalam memperbaiki kualitas peraturan perundangundangan di Indonesia.

Karena itu memadukan tatanan agama, tatanan hukum positif negara, sebagaimana teori siyāsah dīniyyah Ibnu Khaldun. Lebih dari itu nilai-nilai, prinsip-prinsip dan norma adat dan etika sosial yang positif dapat dipadukan dengan hukum negara dalam pendekatan monoisme legal system.

Di mana tatanan negara, agama dan etika sosial harus dapat bekerjasama dalam satu kesatuan integral dalam membangun sistem hukum nasional Indonesia yang integratif artinya suatu sistem hukum yang dipandang relevan dalam menghadapi tantangan dan perkembangan dunia global, di mana elemenelemen sistem hukum nasional baik sistem hukum agama, sistem hukum adat dan sistem hukum produk negara (hukum positif) harus dapat bekerjasama, saling berpangku tangan dalam memberikan konstribusi positif dalam membangun sistem hukum nasional yang kuat dan bermartabat seperti bagan di bawah ini: 


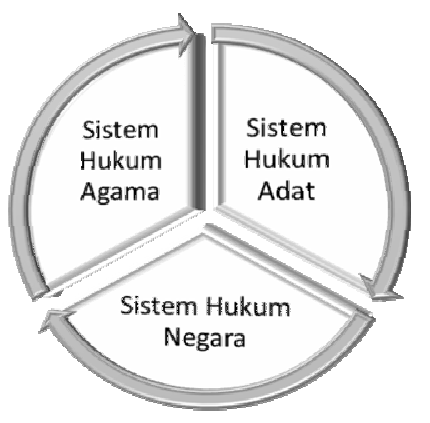

Bagan 2.

Konsep Three Pillars System Hukum Modern yang Integratif

Sumber: Hasil Kajian Penulis Tahun 2014

Melalui Konsep Three Pillars System Hukum Modern yang Integratif tersebut merupakan konsep hukum yang tepat untuk sistem hukum modern Indonesia saat ini untuk mengintegrasikan keanekaragaman budaya, adat istiadat, dan agama yang ada di Indonesia. Keberagaman tersebut merupakan suatu potensi yang jika diberdayakan secara berimbang dan integratif dalam satu sistem hukum nasional yang diharapkan dapat membangun hukum modern Indonesia di masa yang akan datang. Apalagi konsep tersebut akan sangat strategis jika digunakan dalam mengahadapi era globalisasi dewasa ini untuk memfilter masuknya nilai-nilai asing yang tidak sesuai dengan nilai-nilai keindonesiaan.

Jika dihubungkan dengan prinsip snow ball (bola salju), maka sistem bola tersebut diibaratkan suatu sistem hukum yang terus berputar (the legal sistem that turning), bersinergi seperti bola salju yang terus berputar dan semakin lama semakin membesar. Bola sistem hukum nasional inilah yang diharapkan memuat 3 sub sistem di dalamnya terdapat sistem hukum agama, sistem hukum adat, dan sistem hukum negara diharapkan akan saling bekerjasama dan terus bersinergi. Bila ketiga sistem hukum tersebut "dikawinkan" akan "melahirkan" bola sistem hukum nasional yang kuat dalam merobohkan setiap persoalan bangsa yang dihadapi.

Ketiga sistem tersebut baik sistem hukum agama dan sistem hukum adat berkonstribusi dalam perumusan sistem hukum positif negara, demikian pula sistem hukum produk negara tidak boleh bertentangan dengan sistem hukum adat dan sistem hukum agama dan begitu pula sebaliknya sistem hukum adat dan agama tidak boleh bertentangan dengan sistem hukum agama. Ketiga sistem 
tersebut terlembaga secara formal dan balance dalam sistem hukum nasional. Artinya nilai-nilai hukum agama, nilai hukum adat yang bersifat universal terlembaga secara formal dan seimbang dalam pembentukan peraturan perundang-undangan baik dalam landasan, asas maupun dalam norma hukum, materi muatan perundang-undangan.

Hanya dengan itu krisis moral, krisis hukum dengan berbagai permasalahan hukum dan sosial kemasyarakatan yang terjadi di Indonesia dewasa ini seperti maraknya prostitusi, peredaran minuman beralkohol, meningkatnya tingkat perceraian, kemiskinan, berkembangnya homo seks, lesbian, pornogafi dan pergaulan bebas yang kian hari semakin mengkhwatirkan generasi bangsa hanya dapat diatasi dengan mengoptimalkan memberdayakan dan mengintegrasikan norma-norma Islam, seperti memaksimalkan penarikan zakat, penataan pergaulan yang yang islami, pemberlakuan hukum zina dan minuman beralkohol secara tegas, dan penerapan pidana Islam secara bertahap dan lain-lain sebagainya, serta norma-norma sosial dan adat istiadat yang sarat dengan nilainilai luhur ke dalam hukum negara atau hukum positif yang bersifat universal, maka hukum nasional akan mampu memecahkan permasalahan tersebut dan lebih penting sistem hukum nasional akan tetap bertahan (survive) dan bertahan dalam menghadapai berbagai tantangan dan permaslahan bangsa di era globalisasi dan pluralisme hukum yang semakin menglobal.

Menurut Abrar Saleng, dalam konteks konstuksi hukum dan pembangunan hukum nasional, ada perpaduan berbagai nilai. sub-sub sistem yang ada di dalam sistem hukum nasional seperi sistem hukum Islam, sistem hukum adat dapat berkonstribusi dalam membangun sistem hukum nasional. Sistem hukun nasional dan sistem hukum Islam harus saling menerima dan saling memberi dalam membangun sistem hukum yang lebih luas. Namun permasalahan yang sering muncul jika ada perbedaan antara nilai yang satu dengan nilai yang lain. Sehigga diperlukan konsep bagaimana memformulasikan sub sistem dengan sub sistem yang lain bisa saling diterima dan menerima tanpa melihat minoritas dan mayoritas. ${ }^{26}$

Menurut penulis nilai-nilai atau norma-norma Islam yang bersifat universal lah yang dapat masukkan sistem hukum nasional tanpa menyebutkan lebel agama tertentu seperti "nilai-nilai syariat Islam" tetapi nilai-nilai syariat Islam

26Dalam suatu diskusi ilmiah 18 Januari 2014. 
seperrti nilai ilahi, nilai khalïfah, nilai keseimbangan, nilai kemaslahatan dan nilai keadilan, dimodifikasi dengan bahasa hukum nasional yang bersifat universal tanpa menyebutkan itu nilai-nilai Islam. Demikian pula sebaliknya nilai-nilai atau norma-noram agama lain yang positif dan bersifat universal bisa diterima oleh umat lain dapat pula. Sepanjang tidak berkaitan dengan pemaksaan aqidah, ibadah dan budaya agama, atau ajaran-ajaran keyakinan tertentu kepada agama lain. Jika berkaitan dengan masalah-masalah sosial, muamalah, budi pekerti maka nilai-nilai dan norma-norma agama manapun dapat mengambil peran dalam memberikan solusi dalam membangun hukum nasional.

Sehingga hanya nilai-nilai yang memiliki kesamaan yang dapat dipadukan dalam sistem hukum nasional sedangkan nilai-nilai yang berbedah hanya berlaku dalam sistem hukum masing-masing, negara kemudian memberikan perlindungan agar masing-masing sub sistem hukum dapat menjalankan nilai-nilainya dengan baik. Salah satu nilai yang bersifat universal adalah nilai ketuhanan, dimana semua agama di Indonesia menyakini adanya Tuhan.

Konsep yang lain yang bisa diterapkan ke depan adalah memberlakukan dualisme legal sistem yaitu sistem hukum dualistik atau sistem dualism hukum secara nasional. artinya sistem hukum nasional menghidupkan sub sistem yang ada di bawahnya dan memberikan ruang-ruang strategis sesuai dengan konteks yang diperlukan negara atau yang dibutuhkan masyarakat. Artinya sub sistem diangkat menjadi hukum negara yang di-back up secara penuh oleh institusi hukum dan berbagai substansi hukum yang dipelukan.

Seperti halnya di Malaysia yang menganut dualisme hukum, di mana hukum Islam diterapkan bagi mereka yang beragama Islam dengan regulasi dan sistem peradilan Islam. Sedangkan warga Negara Malaysia yang beragama non Islam diberlakukan hukum sipil dengan peradilan sipil pula. Berdasarkan hasil observasi penulis (2013) di Malaysia tempat perjudian seperti togel, ketangkasan mudah kita temukan di tempat-tempat yang telah ditentukan seperti di sekitar kawasan Plaza Idaman, kawasan perjudian di genting Alien dan sebagainya namun tempat-tempat tersebut hanya bisa dimasuki oleh orang-orang non-Muslim. Jika ditemukan orang Islam pribumi maka akan dikenakan saksi berdasarkan akta jinayah Islam persekutuan Malaysia. Demikian pula pengaturan minuman alkohol juga diberlakukan dualisme hukum. Minuman beralkohol dengan mudah di dapatkan di sejumlah supermarket seperti di supermarket KK (KeKe). Namun minuman beralkohol tersebut secara tegas tertulis peringatan "dilarang untuk orang Islam". 
Sehingga tidak tertutup kemungkinan di Indonesia adanya Mahkamah yang bersifat khusus bagi agama tertentu, termasuk berdirinya Mahkamah Syariah di setiap daerah yang telah memiliki perda-perda syariah, seperti yang saat ini diterapkan di Nanggroe Aceh Darussalam dan yang diterapkan di Negara Malaysia.

Demikian pula berkaitan dengan sistem hukum adat, sistem hukum nasional memberikan pengakuan terhadap pengadilan adat di setiap kesatuan-kesatuan masyarakat adat wilayah persekutuan atau wilayah petuanan adat tertentu. Dalam sistem peradilan adat tersebut berlakulah hukum adat yang bersifat khusus, seperti yang terjadi di berbagai wilayah adat di Indonesia. Berdasarkan hasil observasi di desa Kilfura Seram Timur Provinsi Maluku masyarakat menerapkan pengadilan adat secara sederhana, jika terdapat warganya yang meminum minuman beralkohol dan melakukan perbuatan asusila maka kepala adat atau kepala dusun memberikan hukuman kepada yang bersangkutan berupa pukulan kayu, jika pihak orang tua ingin memukul langsung anaknya, maka pihak kepala adat memberikan kesempatan untuk memukul anaknya dan disaksikan oleh petinggi negeri setempat.

Sistem hukum nasional memberikan pengawasan, perlindungan dan jaminan atas pelaksanaan hukum adat dan hukum syariah yang berlaku di daerahdaerah untuk tersebut untuk memastikan pelaksananaan hukum khusus tersebut dapat berjalan dengan baik.

Apabila kedua konsep tersebut dapat dilakukan maka perencanaan pembentukan perundang-undangan nasional harus direkonstruksi dengan memberikan ruang yang seluas-luasnya, masuknya nilai-nilai syariat Islam dan nilainilai hukum adat dalam penyusunan peraturan perundang-undangan di Indonesia. Baik dalam penyusunan landasan, asas sampai pada norma hukum dalam materi muatan ketentuan dalam pasal-pasalnya perundang-undangan.

Sehingga tidak satupun pasal dalam rancangan peraturan perundangundangan yang berdiri sendiri, melainkan diturunkan dari suatu asas hukum di mana asas hukum tersebut merupakan turunan atau penjabaran dari nilai-nilai hukum yang akan ditegakkan dalam peraturan tersebut. Adapun nilai, asas dan norma yang akan dijabarkan harus bersumber dari nilai-nilai syariat Islam atau nilai-nilai agama jika peraturan yang akan dibuat adalah peraturan yang bernuansa agama. Demikian pula apabila peraturan yang dibuat berkaitan dengan memeliharan budaya dan adat istiadat maka nilai, asas dan materi muatan dalam pasal-pasal peraturan tersebut harus bersumber dari nilai-nilai budaya dan adat istiadat tertentu. 


\section{Kesimpulan}

Negara Indonesia memerlukan suatu sistem hukum modern yaitu seperangkat atau suatu sistem hukum yang mampu mengantisipasi serta mengatasi berbagai permasalahan yang mungkin akan timbul. Indonesia sebagai salah satu negara di dunia ini tidak terlepas dari pengaruh arus globalisasi. Sebagai akibat dari globalisasi, juga menimbulkan dampak di bidang hukum. Karena itu salah satu dimensi mutlak dalam pembentukan sistem hukum Indonesia yang modern adalah senantiasa mencerminkan rasa keadilan masyarakat Indonesia dan sesuai cita hukum dan cita-cita moral dalam nilai-nilai Pancasila dan UUD NRI tahun 1945.

Melalui Konsep Three Pillars Sistem Hukum Modern yang Integratif tersebut merupakan konsep hukum yang tepat untuk sistem hukum modern Indonesia saat ini untuk mengintegrasikan keanekaragaman budaya, adat istiadat, dan agama yang ada di Indonesia. Keberagaman tersebut merupakan suatu potensi yang jika diberdayakan secara berimbang dan integratif dalam satu sistem hukum nasional yang diharapkan dapat membangun hukum modern Indonesia di masa yang akan datang. Apalagi konsep tersebut akan sangat strategis jika digunakan dalam mengahadapi era globalisasi dewasa ini untuk memfilter masuknya nilai-nilai asing yang tidak sesuai dengan nilai-nilai keindonesiaan.[w] 


\section{BIBLIOGRAFI}

Ali, Achmad, Menguak Teori Hukum dan Teori Peradilan, Jakarta: Kencana, 2009.

Azhary, M. Tahir, Negara Hukum: Suatu Study tentang Prinsip-prinsipnya Dilihat dari Segi Hukum Islam, Implementasinya pada Periode Negara Madinah dan Masa Kini, Jakarta: Bulan Bintang, 1992.

Anwar, Yesmin, dkk, Sistem Peradilan Pidana: Konsep, Komponen, dan Pelaksanannya dalam Penegakan Hukum di Indonesia, Bandung: Widya Padjajaran, 1988.

Aswanto, "Paradigma di Balik Penyusunan Rancangan KUHP", makalah yang disampaikan pada, seminar publik "Kebebasan Berekspresi dalam Negara Demokrasi: Tinjauan Kritis terhadap RUU KUHP”, di Makassar, tanggal 5 Juli 2006.

Basyir, Ahmad Azhar, Hubungan Agama dan Pancasila, Yogyakarta: Universitas Islam Indonesia, 1985.

Halpern, Manfred, "Toward Futher Modernization of the Study of New Nations", World Politics, No. 17 - October 1964.

Hamka, Islam: Islam Revolusi Ideologi dan Keadilan Sosial, ed. Rusjdi, Jakarta: Pustaka Panjimas, 1984.

Jazuni, Legislasi Hukum Islam di Indonesia, Bandung: Citra Aditya Bakti, 2010.

Mubarak, Ahmad, "Relevansi Tasawuf dengan Problem Manusia Modern', dalam Nurcholis Madjid, dkk. Manusia Modern Mendamba Allah Renungan Tasawuf Positif, ed., Ahmad Nadjib Burhani, Jakarta: IIMaN dan Hikmah, 2002.

Madjid, Nurcholish, Islam dan Kemodernan, Bandung: Mizan, 1987.

Mardjono, Hartono, Menegakkan Syariat Islam dalam Konteks Keindonesiaan, Proses Penerapan Nilai-Nilai Islam, dalam Aspek Hukum, dan Lembaga Negara, Bandung: Mizan, 1997.

Nurhayati, "Tasawuf pada Abad Modern, Solusi Problem Manusia Menurut Seyyed Hossein Nasr", Disertasi, Makassar: PPS UIN Alauddin, 2013.

Pusat Bahasa Departemen Pendidikan Nasional, Kamus Bahasa Indonesia, Jakarta: Departemen Pendidikan Nasional, 2008.

Walisongo, Volume 22, Nomor 1, Mei 2014 
Salman, Otje, dkk., Beberapa Aspek Sosiologi Hukum, Bandung: PT. Alumni, 2012.

Smith, Donald Eugene, Religion and Political Developmen an Analytic Study Boston: Massachusetts, Little, Brown and Company, 1970, diterjemahkan oleh Machnun Husein, Agama dan Modernisasi Politik Suatu Kajian Analitis, Jakarta: Rajawali, 1985.

Sekretariat Jenderal MPR RI, Risalah Perubahan UUD NRI Tahun 1945 Tahun Sidang 2000, Buku Tujuh, Edisi Revisi, Jakarta: Sekretariat Jenderal MPR RI, 2010.

Zainuddin, “Implikasi Pengelolaan Zakat terhadap Keadilan Sosial di Indonesia', Disertasi, Makassar: Universitas Hasanuddin, 2011. 